\title{
SEMIOTIC REVIEW OF VERBAL LITERATURE OF RIWOK KERINCI
}

\author{
Nazurty \\ Universitas Negeri Jambi, Indonesia \\ nazurtysuhaimi@gmail.com
}

\begin{abstract}
Riwok verbal literature is a customary speech text delivered at the ceremonial feast of Sko. This study aims to interpret the expressions contained in the Riwok text through Semiotic Review. This study is a qualitative study using semiotic approach. Semiotic approach used to assess the meaning of the phrase in the text of verbal literature Riwok is based on semiotic theory of Charles Sanders Peirce, namely the triangular theory of meaning or meaning triangle which consists of three main elements, namely the sign, object, and interpretant. Signs, according to Peirce, consists of symbol (signs created from agreement), Icon (sign created from physical representation) and Index (sign created from cause-effect relationships). The results of the study found that in in the expression of Riwok text there are icon, index, and symbol signs. The signs were found in all Riwok texts. Based on the analysis of Riwok text, semiotic signs most commonly found is a sign of symbol. Symbols are found in the phrase which states the requirements for being an indigenous leader, a phrase which states the behavior of leaders, the phrase which states the roles, duties, and functions of traditional leaders, as well as the phrase stating customary sanctions.
\end{abstract}

Keywords: riwok verbal literature; semiotic signs; floklore.

Various verbal literature grows and develops in the Indonesian culture. The verbal literature grows and develops in local culture of Indonesia. Ratna (2007: 27), stated that in the old tradition, verbal literature serves to communicate the values and norms prevailing then to the next generation. Verbal literature or oral traditions also serves to express thoughts, feelings, advice or instructions, and to entertain the public supporting such the culture. Verbal literature or verbal tradition in English is called folklore (Danajaya, 2007: 19).

One form of verbal literature or the verbal tradition is Riwok. Riwok is verbal literature or verbal tradition of Kerinci area. Riwok is a customary speech text delivered at the ceremonial feast, Sko. Riwok Text falls in the category of old Malay literary genre in the form of poetry called as customary word or law words (Karim, 2015:15). Riwok text is delivered during the appointment of traditional leaders who have been chosen by the traditional leaders and prominent elders in the Pulau Tengah village of Kerinci. Sko feast is performed once in three years at a time after the rice harvest. Riwok delivered in every Sko feast is generally the same except for the names of people who is appointed as community leader. Riwok contains the names of people appointed to be a leader in the customary structure and from which tribe of the person comes. Furthermore, the text Riwok also describes the role, duties and functions which must be further carried on. Moreover, the Riwok text also stated the background of the chosen leader and their responsibilities as customary leader and customary sanctions if the customary leader violates the customary norms. Riwok have a language containing aesthetic value as other literary works. The language 
used in Riwok generally contains connotative meanings that have cultural symbols of Kerinci. Therefore, Riwok should be studied through a semiotic approach.

The purpose of this study is to examine the meaning of Riwok through Semiotic Review which is based on Peirce's semiotic theory. Riwok is a verbal literature containing the customary word or law words laden with meaning and cultural values of Kerinci for its supporters. Riwok Text as a customary word or law words that stated the norms applicable in Kerinci culture. It means, Riwok is part of the Kerinci community's culture that reflects the customary norms, cultural behavior, and the rules that apply in the traditional order based on the cultural system of Kerinci. Culture here, refers to a complex of ideas, attitudes, and works of man making it his own and are used to satisfy his life's needs which is obtained by learning continuously, (Koentjaraningrat, 2000: 15-20).

Riwok uses Kerinci language that have aesthetic value or which is a beautiful language. Riwok as of now is presented once in the three-year fixed in ceremonial feast Sko since the custom is still applying as of today. Riwok is a spoken text presented at Sko feast. The person delivering the Riwok or the customary speech already know what to say. Typically, people who deliver Riwok, are people who have important positions in the structure of traditional leaders of Kerinci. So, the person is already accustomed to and understand about Riwok and its expressions and meaning.

To review Riwok, one must first understand the Kerinci language as a medium of expression of Riwok dan understand the culture of Kerinci community. It means, to understand a culture one should first understand the language as a medium which called as language code and culture of supporters as a cultural code. As stated by Teeuw (2003: 331), in order to understand verbal literature, one must first master the language of instruction used as a medium and understand the culture of community of the supporters.

There are some researches that use semiotic review with various forms of literature as the objects. First, Aini (2013: 86) examines the novel Laskar Pelangi by Hirata using a semiotic approach based on semiotics theory of Peirce. This study sought to analyze the meaning of the novel Laskar Pelangi in terms of the icons, indices, and symbols. The description of the research say that the meaning analyzed with a sign icons, indices, and symbols is carried on each sub-sections of the novel. Based on the calculation of the researcher analysis showed that indices are most widely used to interpret the novel.

Second, Uniawati (2007; ....), examined the Fishing Mantra of Bajo: Semiotics Interpretation Riffater. This study examines three issues, including reviewing the meaning contained in the Bajo fishing mantra through heuristic and hermeneutic readings, determine the matrix and the model contained in fishing mantra, and found the inter-textual relations of fishing mantra with other text. This study uses a semiotic approach with of semiotic interpretation theory of Riffater.

Third, the study entitled "Identity of Kerinci People in Kerinci's Verbal Literature". This study is focused on folklore of Kerinci, called kunaung. This study uses a semiotic approach and literary sociology. The findings of this study revealed that the Kerinci people is guided by tradition and religion in all activities. This is illustrated in indigenous proverb, "Tradition is based on Islamic law, Islamic law is based on the Book of Allah". It means that, tradition is based on Islamic law that comes from the Quran and Hadith. Furthermore, Kerinci community adopts parental 
lines, namely lineage which comes by both parents. That is, a child belongs to the family of both parents, and entitled to receive inheritance from a family of both parents.

All three studies mentioned above uses a semiotic approach based on different theory of semiotics with different literary works as the objects. Uniawati's Research (2007; ...), using fishing mantra of Bajo tribe based on Riffater's semiotic theory. Aini's research $(2013 ;$....), which examined the novel Laskar Pelangi by Hirata adopted a semiotic approach based on the semiotics theory of Charles Sanders Peirce. Efrison's research (2008; ....), Examines the Kerinci's people identity in folklore (kunaung) by using a semiotic approach and literature sociology based on the semiotics theory Charles Sanders Peirce.

Even though the research on Riwok verbal literature is based on a semiotic approach, but there are differences with the three studies cited above. First, Uniwati's $(2007 ;$...) examined verbal literature Suko Bajo with a semiotic approach based on semiotic theory of Riffater. Aini (2013) examined the literature with a semiotic approach based on Peirce's semiotic theory, but the object of study is a novel. Meanwhile, Efrison (2008; ....) examined verbal literature of Kerinci by adopting two semiotic approaches namely Peirce semiotic’s theory and literary sociological approach.

Thus, research on Riwok is needed because this study aims to examine and discuss deeper by analyzing the signs of semiotics in the text Riwok which contains customary expressions which became a status symbol, naming of social position, and functions of social life in Kerinci community's culture. In addition, research on Riwok is also beneficial to enrich the study of verbal literature and for preservation and preserving verbal literature, especially literature of Kerinci.

\section{METHODS}

This study is a qualitative research with semiotic approach. Semiotic approaches are used to interpret the representing meaning which is customary words or law words contained in the Riwok text. Interpretation of the meaning in this study is based on the theory of Peirce namely the meaning triangle which consists of three main elements, namely signs, object, and interpretant (Sobur, 2009: 34).

The source of data of this research is Riwok or spoken speech text delivered at the ceremonial feast of Sko in order to appoint traditional leaders in Pulau Tengah village of Kerinci. The data of this study were custom words or law words contained in the Riwok text. The research is conducted through the identification and analysis of signs in the form of symbols, icons, and indexes in Riwok text like the following example:

Riwok Text
Oooi dnge-dnge
kayo nga ribiu dingan rataih!
Nga dudeouk dalam paraik
Nga basudunk mpank
Lawo nga bakatuk duwea
Larak nga bajaje
Lamo nga basapau

Riwok Text

Oooi dnge-dnge

kayo nga ribiu dingan rataih!

Nga dudeouk dalam paraik

Nga basudunk mpank

Lawo nga bakatuk duwea

Lamo nga basapau

\section{Translation}

Oooi listen

Thousand of People with a queen!

Sitting on a trenches

With four corners

And two doors

A parallel array

A swept yard 
Luwok nga bapanghulu

Alo bak sakato rajea

Negeri nga bapagar adenk

Tapio nga bapagar basea

Umoh nga batagane

Basanok basaudarea

Bakaum bakaluargea

Badateok bapanghulu

Badupatai baninik mamok
People with leaders

Nature like the king's words

Country protected by custom

Borders with language as fences

House with teganai

With brothers and sisters

and Familiy

Lead by a Headman

Advised by the elders

The next step is to analyze and interpret data in the form semiotic representation with symbols, icons, and indices to custom words or law words in the Riwok text.

\section{RESULTS AND DISCUSSION}

Riwok is spoken text of customary to appoint of traditional leaders which is presented in the ceremonial feast of Sko in Pulau Tengah Kerinci. The procession for the changing of indigenous leaders is conducted every three years, as such Riwok is presented every three years. Riwok contains custom words or law words that relate to the requirements to become leaders, behaviors, roles, duties, and functions of a traditional leader as well as the customary sanctions for traditional leaders who violate customary norms. To interpret the meaning of the expressions in the Riwok text, a semiotic approach is used a. Semiotics is a model of literary research by analyzing the signs. Such signs represent a certain object representatively (Endraswara, 2009:64).

Expressions contained in the Riwok text generally contain connotative meaning. Connotation is new meaning given by the user of the signs according to his preference, background knowledge or new conventions that exist in the community (Hoed, 2011: 12). In addition, the Riwok text is the text of a speech in the context of traditional ceremonies, namely the appointment of traditional leaders, the more dominantly used language is certainly language in the form of cultural conventions that are of arbitrary nature. Therefore, to interpret the meaning of these expressions, a semiotic approach by Peirce is required namely symbol, icons, and indices which refer to the social and cultural context of Kerinci.

\section{a. Symbol Analysis of Riwok Expressions}

Expressions in the Riwok text uses Kerinci language that generally have connotation meaning which refers to the cultural context of the people of Kerinci. Sign analysis to interpret the expressions in the Riwok text begins from the mark in the form of symbols. According to Pierce symbol is the relationship between the signifier and unnatural signified. This relationship is Arbitrary (arbitrary), or based on the conventions of society (Zoest, 1996: 25). Symbol in literature is language that form words and sentences.

Riwok Text Expression

Oooi dnge-dnge

kayo nga ribiu dingan rataih!

Nga dudeouk dalam paraik

\section{Translation}

Oooi listen

Thousand of people with a queen!

Sitting on a trenches 
Nga basudunk mpank

Lawo nga bakatuk duwea

Larak nga bajaje

Lamo nga basapau

Luwok nga bapanghulu

Alo bak sakato rajea

Negeri nga bapagar adenk

Tapio nga bapagar basea

Umoh nga batagane

Basanok basaudarea

Bakaum bakaluargea

Badateok bapanghulu

Badupatai baninik mamok
With four corners

And two doors

A parallel array

A swept yard

People with leaders

Nature like the king's words

Country protected by custom

Borders with language as fences

House with teganai

With brothers and sisters

and familiy

Lead by a Headman

Advised by the elders

The signs, "trench with four corners" and "and two doors" in the said Riwok text above, is an object of semiotic symbol of a region that has boundaries. The sign "trench with four corners", "and two doors" is a Kerinci community cultural conventions that is arbitrary or lingual typical unit in Kerinci culture to say an area which has boundaries. The Interpretant, "trench with four corners" indicates an area or region with certain boundaries. "and two doors" is a gate that can be opened wide for people going to the area, but the coming in or going out with certain rules that must be obeyed. In addition, the sign "and two door", is also a symbol to say the relationship between the local community or communication with the outside of the area.

Furthermore, the expression "county with leaders" and "nature is in line with the king's words" on the Riwok text above is a semiotic symbol to say that an area has leader that govern them. The sign, "county with leaders" is a cultural agreement of Kerinci people which arbitrarily stated that an area shall have a leader. "Luhak" in Kerinci language means village or country, and the "penghulu" is a leader. So "area with leader" means areas that had leaders. While the sign, "nature is in line with the king's word" is a semiotic symbol which stated that a territory is governed by a leader.

Next, the phrase "county protected by land" is a semiotic symbol which expresses that the region has a norm or rule that must be obeyed by the society. In conclusion, the customary phrase in the Riwok text above is a semiotic symbol which stated that an area has boundaries, there are leaders who set it up, and there was a customary norm as a legal basis in the people's life.

\section{Riwok Text Expression}

Lla dikellah

lah taau dek rupo

Lla dimako

lah taau dek raso

Bajaloa di daleng ayak

bakato di daleng tanoh

Bakilak iko di daleng lubeok

lah taau jantoa dinga batinea

\section{Translation}

Not seen

Already know the shape

Not eaten

Already know the taste

Walking in water

speaking in the ground

Flashing fish in the

Knows the male from the female 
The sign, "Not seen already know with the shape, not eaten already know the taste”, in the Riwok text above is a semiotic symbol of a wise person as the object. The sign, "Not seen already know with the likeness, not eaten already know the taste”, is a typical lingual unit in Kerinci language which is arbitrary in nature used to say that people know how to read the situation and condition through taste or understand meaning through conscience. The interpretation of is people who understand something not with the senses, but through a sense of value or through the conscience of humanity. The sign, "Walking in water speaking in the ground", is a cultural convention of Kerinci to say people can do something that is very difficult or cannot be done by others. The interpretation of walking in the water is something that cannot be done by humans, because human floats on the water instead of walking. Likewise, human beings could not speak in the ground. This is the connotative meaning a work that cannot be done by ordinary people. Thus, the customary phrase in the text Riwok depicts human that has advantage of other human beings. Sign, "flashing fish in the pond already know the male from the female" in the text Riwok mentioned above, is a semiotic symbol of cultural conventions of Kerinci community to call a wise person. The interpretation is, one can understand the desire or the will of another person without explicitly being conveyed. In other words, other people can understand the language implied. Thus, the expression in the text Riwok illustrates, that to become a customary leader in Kerinci culture, one must have a behavior of being able to understand something, either explicitly or implicitly. Additionally, a traditional leader should also have the advantages of other people, namely solving the most difficult problems that probably cannot be done by ordinary people.

\section{b. Icon Analysis of Riwok Customary Expression}

\section{Riwok Text Expression}

Uhang nga jadui sahai inih !

Badengnyuh geppeuk

Imbiu ikeuk

Nyarai kukeuk

\author{
Translation \\ The person being today! \\ is fat \\ With bushy tail \\ and loud nails
}

Sign, "is fat" with "bushy tail" and "loud nail" is a semiotic sign which is an icon which expresses physical representation of a wealthy or prosperous economic, dashing in looks and smart in thinking and acting as well as skilled in speaking. The customary phrase preceded by the phrase, "the person who was inducted as traditional leaders today, is fat, with bushy tail, and loud nails”. That is, the features mentioned in the text are the characteristics that constitute a requirement to become a leader who will be sworn in on that day.

Although, "is fat" "bushy tails", and "loud nails" in the Riwok text mentioned above is contrasted with objects being the symbols of Kerinci culture which is arbitrary to say "prosperous in economy, dashing and charismatic in appearance, smart in thinking and acting and intelligent emotionally, and skilled in speech". However, the phrase "is fat" "with bushy tails", and "loud nails" can be seen as an icon of characteristics of a good leader. In which "fat" represent or similar to the economic well-being, "”a bushy tail” represents dashing and charismatic appearance, and "loud nails" is similar to or represent people who are smart and intelligent and 
good at speaking in public. So, the sign "is fat”, "bushy tail”, loud nail”, in addition to being interpreted with semiotic signs is also an icon that can also be interpreted using a semiotic signs in symbolic form.

\section{Riwok Text Expression \\ Sio-sio manjaloa adenk \\ Sio-sio manjaloa syarok \\ Kaateh idoak bapucak \\ Ka bawoah idoak bauhak \\ Ditengoh-tengoh digihik kumboa}

Anok dipangkau manjadi batiu

Padi ditano tumbeoh lalo

Kunyaik ditano putah isoi

Nyea keno sumpoh

Idoak salamak dunie akhirak

\section{Translation}

Mistaken in performing the culture

Mistaken in performing sharia

No tip on the top

No roots on the bottom

In middle a hole is made by beetle

A kid on a lap turns into stone

A rice is planted into weeds

Turmeric planted white inside

He is sworn upon

Not safe during and after the life

Sign, "A kid on a lap turns into stone" "Rice is planted into weeds", and "Turmeric is planted white inside" is a semiotic signs of an icon in which the object is the unsuccessful attempt. Sign, “A kid on a lap turns into stone” "Rice is planted into weeds", and "Turmeric is planted white inside" in the Riwok text mentioned above is the physical representation of the three forms of business that did not work. Even though the sign, "A kid on a lap turns into stone”, "Rice is planted into weeds", and "Turmeric is planted white inside" is also an object that became a symbol of the cultural conventions of Kerinci society to disclose the of wasteful efforts, these signs appear on the physical representation, the "stone” from "a child", "weeds" from the "rice plant” and "white' from "yellow”. The interpretation "a kid on a lap", is a man who has a mind that can be educated with good morals. While the "stone" is an inanimate object that has no mind and will not change even with any effort. "Rice plant" is staple food in Kerinci, while the weeds are type of grass that are not useful, and it even disturb the plant. "Rice is planted" means an effort to get food, but "weed" grass is growing to disturb the plants. "Turmeric" is a plant with yellow tuber, in addition to a cooking, it is also used for food coloring. Turmeric plan is expected to produce yellow tubers but it turns white, that expectations do not match reality. In other words, it is businesses that fails to get good results.

The sign, "A kid on a lap turns into stone" "Rice is planted into weeds", and “Turmeric is planted white inside”, in Riwok text mentioned above was preceded by a statement for anyone who are mistakenly performing the custom and sharia will be sworn upon by the ancestors, namely all forms of his efforts this world will not succeed. This illustrates that the phrase can also be seen as an index with the object of if one mistakenly futile run will be subject to customary and syarak oath ancestors. It means that, the sign, "A kid on a lap turns into stone" "Rice is planted into weeds", and "Turmeric is planted white inside", is the result of the sign, "mistaken in performing the custom" and "mistaken in performing sharia" and the sign "He is sworn upon to be unsafe in the life and the after life". Thus, the phrase in the text Riwok illustrates that in the customs and culture of the people Kerinci, a leader must be able to perform custom and sharia properly. If, norms and rules of customs and sharia are not executed properly it is believed he will be sworn upon by the ancestors 
which will adversely affect them. That's a reflection of the implementation of the indigenous culture of the people of Kerinci.

\section{c. Index Analysis of Customary Expression \\ Riwok Expression Text \\ Anok dipangkau \\ Panako dibimbi \\ Manimbang samo berrek \\ Manyukank samo panjeng \\ Mamakoa abih \\ Mamenggoa putaih \\ Bbeo idoak buleh nulok menyang \\ Jangoa adea duhi daloa dagi \\ Mambuneah idoak buleh duo kalai \\ Translation \\ A kid is put on the lap \\ Nephews and nieces' hands are held \\ Weighing equally \\ Measuring equally \\ Eating completely \\ Severing fully \\ Bamboo sprout may not reject miyang \\ No thorn in the side \\ No killing twice}

The signs, “A kid is put on the lap, nephew and niece's hands are held” and the sign "Weighing equally, measuring equally", are semiotic signs in form of index which refers to the object "child" which means the direct descendant and "nephew and niece" are persons in our surrounding whose lineage is equal to the children. It means that children are our full responsibility, while we play a role in helping to guide nephew and nieces. The sign, “A kid is put on the lap, nephew and niece's hands are held" is a causal relationship. Kids are the direct descendants and parents must take full responsibility for them. Meanwhile, nephew is a member of family or relatives that is not under direct lineage and the surrounding communities. As a leader, one shall also take responsibility for helping guide the community environment. The phrase, contrasting these two expressions, namely "A kid is put on the lap" and "nephew and niece's hands are held". So is the sign "Weighing equally, measuring equally", is the result of its role as a leader then it should be fair. Fairness in society is the result of its role as a leader.

Although, the sign "Weighing equally, measuring equally", is a sign of semiotic in form of an index, this phrase can also be seen as a sign of semiotic in form of symbol. The phrase is a cultural convention of Kerinci society to arbitrarily say "fair behavior" of an indigenous leader.

Similarly, the sign, "Eating completely”, "Severing fully ", are semiotic signs in the form of index in which the object is to resolve the issue completely. The interpretation is, a leader must resolve the issue once and for all so that he can take decisions firmly. Behavior of resolving problems completely and making decision firmly is a necessary for a leader to be able to resolve all the problems that exist in society. The behavior of resolving problems thoroughly and making decisions firmly is the result of his role as a leader.

Although, the sign, "Eating completely", "Severing fully", are semiotic signs in the form of an index, but the phrase can also be interpreted symbolically. The sign, "Eating completely”, "Severing fully”, is a cultural convention in Kerinci society to arbitrarily say "solve the problem completely and firmly". Also pay attention to the following Riwok text!

Riwok Text Expression

Dupatai Suko barajea

Uhang nga bakapalo dingi
Translation

Depati Suko Berajo

People who are levelheaded 
Badadu lampo

Taau manyelesaikan silang salisih

Manjarnihkan ayak nga kerrah

Taau pulo manyukant dinga manimbang
A big heart

Knows how to resolve differences

Clear up the murky water

Knows also to measure and weigh

Sign, "People who are level headed with big heart", "knows how to resolve differences", "clear up the murky water", "knows also measure and weigh" of the traditional proverb text mentioned above can also be seen as a sign of semiotic form of an index. This sign appears on the causal relationships in which the object is people who knows how to resolve differences fairly and justly because he is a levelheaded and bighearted. The interpretation is someone who can solve the problems of others properly and able to determine the right from wrong because he's level-headed and bighearted. It means that a person who can solve the problems of others are levelheaded people with big heart.

Although, the sign "clear up the murky water", appears as an index or causation of the sign, "levelheaded and bighearted", but these signs may be contrasted with objects which become the symbols or cultural conventions of Kerinci to say "solving a problem". It means that the sign "clear up the murky water", in addition to being interpreted as an index, it can also be interpreted as a symbol.

\section{CONCLUSION}

Based on the analysis of Riwok texts as described above, it can be summarized as follows.

a. Riwok describes traditional boundaries, leadership in the customary area, customary norms, requirements, behavior, roles, duties, and functions of traditional leaders in the culture of Kerinci.

b. The semiotic sign most commonly appear in the Riwok text is a sign in the form of symbols, namely lingual unit typical in Kerinci language that is arbitrary or sign which is the culture convention in Kerinci.

c. There are some semiotic signs found in Riwok text that appears in the form of an icon namely the sign that appears in the form of a physical representation.

There are some semiotic signs found in Riwok text in the form of an index, which is a sign that appears on cause-effect relationships.

\section{REFERENCES}

Aini, Alfiah Nurul. Analisis Semiotik Terhadap Novel Laskar Karya Andrea Hirata.NOSI Volume 1, Nomor 2, Agustus 2013

Dananjaja, James. Fofklor Indonesia: Ilmu Gosip, Dongeng, dIl. Jakarta: Pustaka Utama Grafiti, 2007.

Endaswara, Suwardi. Metode Penelitian Folklor Konsep, Teori, dan Aplikasi. Yogyakarta: Media Pressindo, 2009. 
Efrison. Jati Diri Masyarakat Kerinci dalam Sastra Lisan Kerinci. Medan: Universitas Sumatera Utara, 2008.

Hoed, Benny H. Semiotik \& Dinamika Sosial Budaya. Jakarta: Komunitas Bambu, 2011.

Koentjaraningrat. Kebudayaan, Mentalitas, dan Pembangunan. Jakarta: Gramedia, 2000.

Karim, Maizar. Menyelisik Sastra Melayu. Yogyakarta: Histokultura. 2015.

Ratna, Nyoman Kutha. Estetika Sastra dan Budaya. Yogyakarta: Pustaka Pelajar, 2007.

Sobur, Alex. Semiotika Komunikasi. Bandung: Remaja Rosdakarya, 2003.

Teeuw, A. Sastra dan Ilmu Sastra. Jakarta: Pustaka Jaya, 2003.

Uniawati. Mantra Melaut Suku Bajo: Interpretasi Semiotik Riffaterre. Semarang: Pascasarjana Unversitas Diponegoro. 2007.

Zoest, Aart Van. Semiotika. Translated by Ani Soekowati. Jakarta: Yayasan Sumber Agung. 1996. 